\title{
Iron Dialyzability in a Multiple Nutrient Formulation and Effect of the Addition of Separate Nutrients
}

\author{
Luciana Bueno*, Se Ima Freire de Carvalho Cunha, Julio Sé rgio Marchini, \\ José Eduardo Dutra de Oliveira
}

Department of Internal Medicine, Faculty of Medicine of Ribeirao Preto, University of Sao Paulo, Ribeirao Preto, SP, Brazil

\begin{abstract}
Introduction: Different nutrients added to nutritional formulations can facilitate, reduce or block the iron absorption. Objective: The aims of this study was to assess the modulation of iron bioavailabily by other minerals and vitamins in an multiple nutrient formulation and in an aqueous iron solution. Material and Methods: We analyzed the iron dialy zability in the multiple nutrients formu lation developed to simulate an enteral diet. Furthermo re, the iron dialy zability was determined in aqueous solutions containing $25 \mathrm{mg}$ of iron, which were added separately usual amounts of soluble fiber, salt mixture, vitamin mixture, calcium and vitamin C. The dialysed iron was measured by atomic absorption spectrometry. Results: In the multip le nutrients formu lation, we docu mented low bioavailab ility of iron $(0.80 \pm 0.01 \%)$. Co mpared with the aqueous iron solution $(70.0 \pm 6.0 \%)$, the addition of $135 \mathrm{mg}$ of vita min $\mathrm{C}$ increased the iron dialy zability $(90.0 \pm 3.0 \%)$. There was reduction of iron dialysis after addition of soluble fiber $(1.00 \pm 0.01 \%)$, the vitamin mixture $(25.00 \pm 0.12 \%)$, salt mixture $(2.00 \pm 0.06 \%)$ and calcium $(0.80 \pm 0.02 \%)$. Conclusion: The low iron bioavailability in the mu ltiple nutrients formulation can be attributed to the protein source and supply of fiber and calcium, thereby affecting the absorption of iron.
\end{abstract}

Keywo rds Bioavailability, Iron, Soy Protein, Soluble Fiber, Calcium

\section{Introduction}

Iron absorption is affected by body iron stores, by the chemical structure of the salt, and by dietary factors (1) which have positive or negative effects on iron bioavailability $(2,3)$. The solubility, dialyses, and entry/transport of iron by Caco-2 cells are in vitro methods used to assess the addition of nutrients on bioavailability of iron. In vitro dialyzability analysis the iron dialyzes through a semi-permeable membrane after simulation of gastric and duodenal digestion (4) represents a methodological option for the assessment of iron bioavailability after the addition of different nutrients. This methodology may provide useful information on iron bioavailability in foods and dietary products (5), like oral supplement and enteral diet.

Patients unable to consume sufficient quantities of food to satisfy their nutrient requirements need oral supplement or enteral nutrition (6). The possible interactions between the components of the formu la may alter the bioavailability of specific nutrients and interfere with the clin ical course of sick individuals. The aims of this study was to assess the modulation of iron bioavailabily by other minerals and vitamins in an multiple nutrient formulation and in an iron

\footnotetext{
* Corresponding author:

lubuenno@yahoo.com.br (Luciana Bueno)

Published online at http://journal.sapub.org/medicine

Copyright (C) 2012 Scientific \& Academic Publishing. All Rights Reserved
}

aqueous solution.

\section{Materials and Methods}

\subsection{Preparation of The Experimental Formula and of the Aqueous Solutions}

We prepared a multiple nutrient formulation that would reproduce the nutrient composition of products used for oral supplementation or polymeric enteral diet (Table 1). All components (protein soy isolate, maltodextrin, canola and corn oils, soy lecithin, partially hydrolyzed guar gum, and a mixture of minerals and vitamins) used to prepare the formulation were purchased. In parallel, we prepared an aqueous ferrous sulphate solution containing $25 \mathrm{mg}$ elemental iron to which the following nutrients were later added: partially hydrolyzed guar gum (25 g); salt mixture (3 g); vitamin mixture (10 g); calcium (800 $\mathrm{mg})$; and vitamin $\mathrm{C}$ $(135 \mathrm{mg})$. A total volume of $250 \mathrm{~mL}$ and an iron concentration of $25 \mathrm{mg}$ were kept constant regardless of the nutritional composition of the enteral formula or aqueous iron solution.

\subsection{Digestion and Dialyzability of the Samples}

The in vitro bioavailability of iron in the samples was determined by the method of Miller and others (7) and modified by Luten and others (8). For the simulation of the digestive process, a $250 \mathrm{~mL}$ sample of the multip le nutrient 
formulation was homogenized and $6 \mathrm{~N} \mathrm{HCl}$ was added until a $\mathrm{pH}$ value of 2 was reached. Five $20 \mathrm{~g}$ aliquots were separated and pepsin was added at the proportion of $0.125 \mathrm{~g} / \mathrm{g}$ protein. The solution was incubated at $37{ }^{\circ} \mathrm{C}$ in a water bath with shaking for $2 \mathrm{~h}$. Finally, titration with $0.5 \mathrm{~N} \mathrm{KOH}$ was performed up to $\mathrm{pH}$ 7. A sodium bicarbonate solution was prepared and added to the dialysis tube until $\mathrm{pH} 5$ was reached after $30 \mathrm{~min}$ under constant shaking. The pancreatin-bile solution was then prepared at the proportion of $25 \mathrm{mg}$ pancreatin/g protein in the sample and of $0.4 \mathrm{~g}$ pancreatin/2.5 g bile extract. The pancreatin-bile solution (4 $\mathrm{mL}$ ) was added to 3 beakers containing $20 \mathrm{~g}$ of the digest and the mixture was incubated in a water bath with shaking for $2 \mathrm{~h}$.

The process was finalized by removing the dialysis tubes from the solutions and the content of the beakers was transferred to a $25 \mathrm{~mL}$ volumetric round-botton flask and reconstituted to its final volume with deionized water. For the samples of aqueous solutions containing $25.0 \mathrm{mg}$ iron, only $\mathrm{pH}$ control was performed by acidification and neutralization with the reagents used in the method, without the addition of digestive enzy mes.

For the evaluation of iron dialy zability, $20 \mathrm{~g}$ of the digest or of the aqueous solutions was placed in a beaker together with the dialysis tube previously hydrated in deionized water for $10 \mathrm{~min}$ and filled with $25 \mathrm{~mL}$ of an $\mathrm{NaHCO}_{3}$ solution. The flasks were covered and kept in a water bath at $37{ }^{\circ} \mathrm{C}$ with shaking for $30 \mathrm{~min}$. Four $\mathrm{mL}$ of the bile-pancreatin suspension was added to each flask and incubation was continued for 2 additional hours. At the end of the incubation period the dialyzed content was transferred to volumetric balloons and deionized water was added to complete the volume to $25 \mathrm{~mL}$, followed by storage in a freezer at $-20^{\circ} \mathrm{C}$ until the time for reading.

\subsection{Determination of Total and Dialyzed iron}

For the determination of total iron in the aqueous solutions and in the various formulations tested, $2 \mathrm{~g}$ samples were obtained and digested with nitric acid $\left(\mathrm{HNO}_{3}\right)$ and hydrogen peroxide $\left(\mathrm{H}_{2} \mathrm{O}_{2}\right)$ at a $5: 1$ proportion at $100{ }^{\circ} \mathrm{C}$ in a block digestor (Pyrotec ${ }^{\circledR}$ ). The material was diluted with deionized water in a $50 \mathrm{~mL}$ round-botton flask. The analyses were performed using a Shimadzu ${ }^{\circledR}$ atomic absorption spectrophotometer model AA 6200 (Shimadzu Corporation,
Tokio, Japan) with an air/acetylene oxidant under the following conditions: hollow cathode lamp, 248.3 wavelength for iron and a $0.2 \mathrm{~nm}$ slit. The solutions for the standard iron curve were prepared with Tritisol ferric chloride $\left(\right.$ Merck $^{\circledR}$ 9972) at concentrations of $0.5,2.0$, and 4.0 $\mu \mathrm{gFe} / \mathrm{mL}$. All determinations were carried out in triplicate and data are reported as means + SD.

Iron dialy zability was estimated as the proportion of dialyzed iron in relation to iron concentration at the beginning of the in vitro digestion process after a period of equilibrium through the dialys is membrane.

\section{Results}

Table 2 shows that percent dialyzed iron was very low in the mu ltip le nutrient formu lation $(0.80 \pm 0.01 \%)$, indicating a possible impairment of iron bioavailability in products used in enteral formula, like this multiple nutrient formulation. In aqueous solutions, iron dialy zability was facilitated by the addition of ascorbic acid $(90.00 \pm 3.00 \%)$, and was reduced by the addition of guar gum $(1.00 \pm 0.01 \%)$, and calcium carbonate $(0.80 \pm 0.02 \%)$.

\section{Discussion}

In the present study, iron dialyzability in a multiple nutrient formulation was very low $(0.80 \pm 0.01 \%)$. This study's results confirm the inhibitory effect of calcium and of soluble fiber on iron bioavailability assessed by the method of in vitro dialy zability.

Ascorbic acid has long been known to enhance absorption of iron from test meals (9). Despite the presence of vitamin $\mathrm{C}$, the iron dialyzability was low from multiple nutrient supplements, indicating that other factors were harming the bioavailability of iron. Calcium carbonate was used in the present study, that possibly determined the formation of insoluble complexes with iron, explaining the inhibitory effect of the addition of calcium on the iron dialyzability $(10,11)$. A negative effect on iron absorption has been documented with calcium phosphate (12) and calcium carbonate (13) supplementation, although this effect did not occur in a radio is otope study on humans (14) or in experiments of iron dialy zability (15).

Table 1. Nutritional composition of $250 \mathrm{~mL}$ of a mult iple nutrient solution

\begin{tabular}{|c|c|}
\hline Nutrient & Sources and composition \\
\hline Protein & Soy protein isolate $(3.1 \mathrm{~g})$ \\
\hline Carbohydrate & Maltodextrin $(63.1 \mathrm{~g})$ \\
\hline Lipid & Corn oil $(1.0 \mathrm{~g})$, canola oil $(3.5 \mathrm{~g})$, soy lecithin $(0.3 \mathrm{~g})$ \\
\hline Fiber & Partially hydrolyzed guar gum $(25.00 \mathrm{~g})$ \\
\hline Salt mixture & 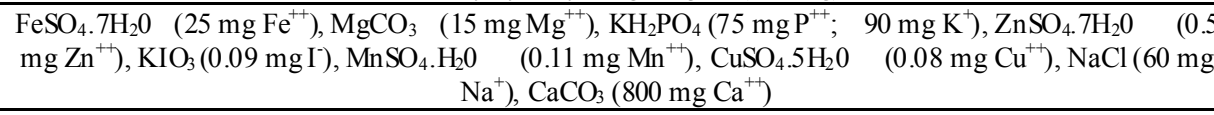 \\
\hline Vitamin mixture & $\begin{array}{c}\text { Vitamin } \mathrm{A}(50 \mu \mathrm{gRE}) \text {, vitamin } \mathrm{D}(0.4 \mu \mathrm{g}) \text {, vitamin } \mathrm{E}(0.8 \mathrm{mg} \mathrm{TE}) \text {, vitamin } \mathrm{K}(4.0 \mu \mathrm{g}) \text {, vitamin } \mathrm{B}_{1}(0.1 \mathrm{mg}) \text {, } \\
\text { vitamin } \mathrm{B}_{2}(0.1 \mathrm{mg}) \text {, niacin }(1.0 \mathrm{mg}) \text {, pantothenic acid }(0.5 \mathrm{mg}) \text {, vitamin } \mathrm{B}_{6}(0.15 \mathrm{mg}) \text {, folic acid }(15.0 \mu \mathrm{g}) \text {, } \\
\text { vitamin } \mathrm{B}_{12}(0.5 \mu \mathrm{g}) \text {, biotin }(12.0 \mu \mathrm{g}) \text {, vitamin } \mathrm{C}(5.0 \mathrm{mg})\end{array}$ \\
\hline
\end{tabular}


Table 2. Mean and standard deviation of percent iron in a pure aqueous solution (A) or in the same solution after the addition of individual components (B, C, D, E and F) and in the nutritionally complete formulation (G)

\begin{tabular}{lcc}
\hline & Formulation & Dialyzed iron (\%) \\
\hline A & Aqueous iron solution & $70.00 \pm 6.00$ \\
\hline B & Aqueous iron solution + guar goma & $1.00 \pm 0.01$ \\
\hline $\mathrm{C}$ & Aqueous iron solution + salt mixture & $2.00 \pm 0.06$ \\
\hline $\mathrm{D}$ & Aqueous iron solution + vitamin mixture & $25.00 \pm 0.12$ \\
\hline $\mathrm{E}$ & Aqueous iron solution + calcium carbonate & $0.80 \pm 0.02$ \\
\hline $\mathrm{F}$ & Aqueous iron solution + vitamin C & $90.00 \pm 3.00$ \\
\hline $\mathrm{G}$ & Multiple nutrient formulation & $0.80 \pm 0.01$ \\
\hline
\end{tabular}

In vitro methods are relatively simple, rapid and inexpensive and can simulating the digestion gastric and duodenal, followed by dialysis. The proportion of the element diffused through the semi permeable membrane during the process, is the dialysability element after an equilibration period, being used as an estimate of nutrient bioavailability (7-8).

In a collaborative study to compare the methods using in vitro and in vivo to assess the absorption of non-heme iron, found a statistically significant correlation indicating that the results obtained using the method in vitro can be extrapolated to humans (8).

In vitro studies have shown that iron absorption from breakfast cereals was reduced after the addition of fibers (16) and also in foods such wheat, rice, corn and soy (17). In contrast to these findings, rats fed with partially hydrolyzed guar gum presented greater intestinal iron absorption than rats receiving a diet without the addition of fiber (18). In a study on healthy humans, the daily addition of $40 \mathrm{~g}$ soluble fiber to a mixed diet did not alter the apparent absorption of iron (17). The discordance in the literature regarding the effect of fibers on iron bioavailability may be attributed to differences in the potential of soluble or insoluble fibers to form precipitate that limit iron absorption. There is also the hypothes is that the consumption of soluble fiber will increase the bacterial flora, resulting in a stimulus of iron absorption by the colonic mucosa $(18,19)$ and explaining the difference between in vitro and in vivo studies. Thus, when the content of soluble fiber is modified in formulations, it is possible that in vitro methods will not be feasible for the assessment of iron bioavailability.

This multip le nutritional formulation was studied because is similar to enteral nutrition who composited by multiple nutrients and offered to people in the same time.

In various commercial enteral diet products, percent dialyzed iron ranged from 2.34 to $9.67 \%$ according to the presence of fiber and to the calcium-iron proportion (20). The study of optimization of dialyzed iron in a multiple nutrient solution showed that the ideal formulation for a maximum of $7 \%$ dialy zability required $10 \mathrm{mg} / \mathrm{L}$ iron, 10 $\mathrm{g} / \mathrm{L}$ fiber, $320 \mathrm{mg} / \mathrm{L}$ calcium and no addition of medium-chain triacylg lycerides (21).

In the present study, the highest concentration of nutrients of the solution can justify poor results of both the iron dialyzabilidade formula with multiple nutrients and in aqueous solution of ferrous sulfate. The enteral formula used in this study contains soy protein extract, which is known to decrease iron absorption (22-24). The inhibitory effect of soybean products is thought to be due to the protein component (7) than phytic acid (25).

Cook et al. (14) assessed the effect of calcium salts commonly used as supplements on iron absorption when administered during the interval between meals and observed that calcium carbonate at the dose of $600 \mathrm{mg}$ did not inhibit the absorption of ferrous sulfate $(18 \mathrm{mg})$, at an iron/calcium proportion of 1:33). When the same assays were repeated using citrate and phosphate salts as a source of calc ium at the same concentrations, iron absorption was reduced to $44 \%$ and $62 \%$, respectively, showing that the type of salts used can also affect the bioavailability of minerals. Reddy \& Cook (26) observed that different iron/calcium proportions (above 1:40) and the types of salt sources of the minerals interfere with the bioavailability of iron.

Yoon et al. (27) discussed the possibility of fiber acting on the human gastrointestinal tract by causing changes in the utilization of nutrients and showed that greater amounts of fiber (>20 g/day) can affect the bioavailability of minerals. The supplements studied here contained $25 \mathrm{~g}$ fiber that may have represented a factor capable of reducing iron absorption.

Numerous interactions exist between the different trace elements affecting absorption via the gastrointestinal tract. Factors affecting bioavailability of trace elements include the actual chemical form of the nutrient (eg, organic form of iron is better absorbed than the ionic form), antagonistic ligands (eg, zinc absorption is decreased by phytate and fiber; iron absorption is decreased by fiber), facilitatory ligands (eg, zinc absorption is aided by citric acid or iron absorption is increate by amino acids or fermented products ), and competitive interactions (eg, iron depresses the absorption of copper, and zinc; zinc depresses copper absorption and vice versa) (28).

Studies evaluating the effect of different protein, fiber and calcium sources on iron dialy zability in multiple nutrition formulation are needed in order to provide an adequate nutrition supply without a reduction in iron bioavailability. The iron bioavailability in a multiple nutrient solution proved to be low, a fact that may harm the health of individuals who use enteral nutrition. 


\section{REFERENCES}

[1] Péneau S, Dauchet L, Vergnaud AC, Estaquio C, Kesse-Guy ot E, Bertrais S, Latino-Martel P, Hercberg S, Galan P. Relationship between iron status and dietary fruit and vegetables based on their vitamin $\mathrm{C}$ and fiber content. Am J Clin Nutr. 2008;87:1298-305.

[2] Reddy MB, Hurrel RF, Cook JD. Meat consumption in a varied diet marginally influences nonheme iron absorption in normal individuals. J Nutr. 2006;36:576-81.

[3] Ma G, Jin Y, Plao J, Kok F, Guusje B, Jacobsen E. Phytate, calcium, iron, and zinc contents and their molar rations in foods commonly consumed in China. J Agric Food Chem. 2006;53:10285-90

[4] Drago SR, Valencia ME. Influence of Components of Infant Formulas on in Vitro Iron, Zinc, and Calcium Availability. $\mathrm{J}$ Agric Food Chem. 2004;52:3202-7.

[5] Reddy MB. Algorithms to assess non heme iron bioavailability. Int J Vitam Nutr Res. 2005;75:405-12.

[6] Sicchieri JJF, Unamuno MRDL, Marchini JS, Cunha SFC. Evolução antropométrica e sintomas gastrointestinais em pacientes que receberam suplementos nutricionais ou nutrição enteral. Rev Assoc Med Bras. 2008;5:149-52.

[7] Miller DD, Schricker BR, Rasmussen RR, Van Campen D. An in vitro method for estimation of iron availability from meals. Am J Clin Nutr. 1981;34:2248-56.

[8] Luten J, Crews H, Flynn A, Van Dael P, Kastenmayer P, Hurrel R, et al. Interlaboratory trial on the determination of the in vitro iron dialysability from food. J Sci Food Agric, 1996;72:415-24.

[9] Atanassova BD, Tzatchev KN. Ascorbic acid--important for iron metabolism. Folia Med (Plovdiv). 2008;50:11-6.

[10] Perales S, Barberá R, Lagarda MJ, Farré R. Fortification of milk with calcium: Effect on calcium bioavailability and interactions with iron and zinc. J Agric Food Chem. 2006;54:4091-6.

[11] López MA, Martos FC. Iron availability: An updated review. Int J Food Sci Nutr. 2004;55:597-06.

[12] Monsen ER, Cook JD. Food iron absorption in human subjects. IV. The effect of calcium and phosphate salts on the absorption of non heme iron. Am J Clin Nutr. 1976;29:1142-48.

[13] Dawson-Hughes B, Seligson FH, Hughes VA. Effects of calcium carbonate and hydroxyapatite on zinc and iron retention in postmenopausal women. Am J Clin Nutr. 1986;44:83-8.

[14] Cook JD, Dassenko SA, Whittaker P. Calcium supplementation: effect on iron absorption. Am J Clin Nutr. 1991;53:106-11.
[15] Van Dyck K, Tas S, Robberecht H, Deelstra H. The influence of different food components on the in vitro availability of iron, zinc and calcium from composed meal. Int J Food Sci Nutr. 1996;47:499-06.

[16] Wortley G, Leusner S, Good C, Gugger E, Glahn R. Iron availability of a fortified processed wheat cereal: a comparison of fourteen iron forms using an in vitro digestion/human colonic adenocarcinoma $(\mathrm{CaCo}-2)$ cell model. $\mathrm{Br} \mathrm{J}$ Nutr. 2005;93:65-71.

[17] Freitas KC, Amancio OM, Ferreira Novo N, Fagundes-Neto U, De Morais MB. Partially hydrolyzed guar gum increases intestinal absorption of iron in growing rats with iron deficiency anemia. Clin Nutr. 2006;25:851-8.

[18] Coudray C, Bellanger J, Castiglia-Delavaud C, Rémésy C, Vermorel M, Rayssignuier Y. Effect of soluble or partly soluble dietary fibres supplementation on absorption and balance of calcium, magn esium, iron and zinc in healthy young men. Eur J Clin Nutr. 1997;51:375-80.

[19] Azevedo CH. Avaliação in vitro da disponibilidade de ferro em dietas enterais submetidas a duas condições digestivas. [Dissertação] Faculdade de Ciências Farmacêuticas: Universidade de São Paulo 2001.

[20] Bueno L. Efeito do triacilglicerídeo de cadeia média, fibra e cálcio na disponibilidade de ferro, magnésio e zinco em uma formulação de alimentação enteral com otimização conjunta para os três minerais. Ciênc Tecnol Aliment. 2008;28:1-10.

[21] Visentín AN, Drago SR, Osella CA, de la Torre MA, Sánchez HD, González RJ. Effect of the addition of soy flour and whey protein concentrate on bread quality and mineral dialyzability. Arch Latinoam Nutr. 2009;59:325-31.

[22] Etcheverry P, Hawthorne KM, Liang LK, Abrams SA, Griffin IJ. Effect of beef and soy proteins on the absorption of non-heme iron and inorganic zinc in children. $\mathrm{J}$ Am Coll Nutr. 2006;25:34-40.

[23] Lynch SR, Dassenko SA, Cook JD, Juillerat MA, Hurrell RF: Inhibitory effect of a soybean-protein-related moiety on iron absorption in humans. Am J Clin Nutr. 1994;60:567-72.

[24] Kane AP, Miller DD. In vitro estimation of the effects of selected proteins on iron bioavailability. Am J Clin Nutr. 1984;39:393-401.

[25] Hallberg L, Rosander L. Effect of Soy Protein on Non-heme Iron Absorption in Man. Am J Clin Nutr. 1982;36:514-20.

[26] Reddy MB, Cook D. Effect of calcium intake on nonheme-iron absorption from a complete diet. Am J Clin Nutr 1997; 65: 1805-20.

[27] Yoon S, Chu D, Juneja LR. Chemical and physical properties, safety and application of partially hydrolyzed guar gum as dietary fiber. J Clin Biochem Nutr 2008; 42: 1-7.

[28] Sriram K, Lonchyna V.A. Micronutrient Supplementation in Adult Nutrition Therapy: Practical Considerations. JPEN J Parenter Enteral Nutr 2009 33: 548-62. 